\title{
実操業浮選プロセスの速度論的解析 ${ }^{*}$
}

\author{
連続式浮選プロセスのシミュレーションに関する研究(第 3 報)——
}

\author{
柳 沢 之彦 ${ }^{1}$ 井上外志 雄 $^{2}$ \\ 今 泉 常 正 $^{3}$
}

\section{1. 緒論}

浮選過程の速度論的研究を進めることにより，半回分式 浮選と連続式浮選の間の定量的な関係付けが可能となり, 浮選系あるいはその制御系の設計に必要な多くの有用な情 報を得ることができると考えられている。著者らはその手 掛かりとなるプロセスの数学モデルを開発することを目的 として, 浮選プロセスのシミュレーションに関する研究を 行なつた。まず第 1 報に㧊いて, 浮選セル内の流れ特性を 逆混合モデルで記述することを提案した。第 2 報において, 浮選過程が一次反応速度式に従い，その速度定数は離散的 に分布するものと想定してモデルを作成し，実験室試験に おける黄銅鉣の浮選挙動に関して，その妥当性を検証した。 本報告では鹿間選鉱工場に扔ける実操業浮選プロセスにつ いてモデルの検証を試みた。当該工場では $\mathrm{Pb} 0.4 \%, \mathrm{Zn}$ $3.7 \%$ の鉛・亜鉛鉱 $3,100 \mathrm{t}$ /日をバルク優先浮選方式で処 理している (Fig. 1，1976年 10 月現在 )。

\section{2. 浮選プロセスモデル}

対象とした連続浮選セルの流孔特性として, 逆混合モデ ルを適用した。また, その浮選過程は一次反応速度式に従 い, かつその速度定数 $k$ は離散的に分布するものと想定し $た_{0}^{2) 3)}$ 第 2 報に述べたように， $k_{i}$ とその分布率 $\xi_{i}$ は，半 回分式浮選速度曲線から，接線近似による図式解法および 最小二乗法により求めることとした。 なお捊選系内のフロ

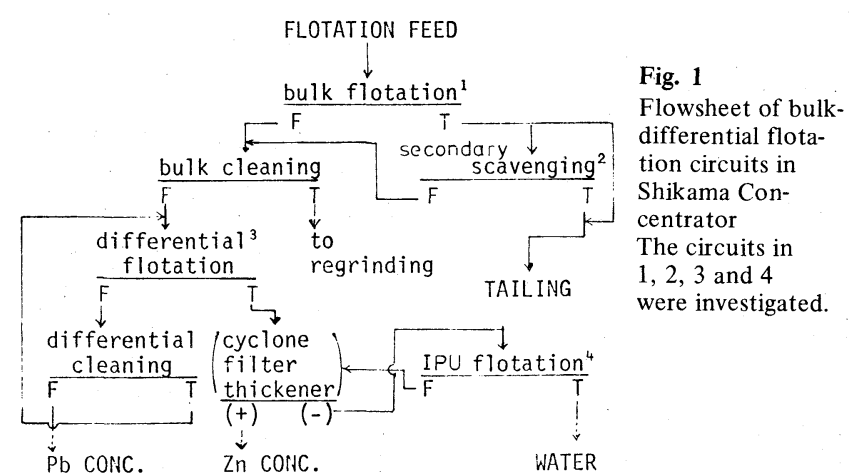

\footnotetext{
* 1978 年 9 月 29 日受理 昭和 52 年 4 月 6 日日本鉱業会春季大会に おいて一部発表

1. 正会員 工博 公害資源研究所資源第 3 部

2. 正会員 工博 東京大学助教授 工学部資源開発工学科

3. 正会員 工博 東京大学教授 工学部資源開発工学科
}

ス相をパルプ相から切離して別個に考慮することは行なわ なかつた。

\section{3. 実操業浮選セルにおけるパルプの滞留時間分布}

実操業浮選プロセスにおいて, cell-to-cell 方式の 浮選セルに拄けるパルプの流孔特性は, 完全混合槽直列モ デルで記述されることが報告されているが,゙フリーフロー 方式に関する報告はほとんど見当らない。著者らは食塩を トレーサとしたインパルス応答試験により,フリーフロー 方式を含む各種浮選回路におけるパルプの滞留時間分布を 測定し，流れ特性の推定を試みた。

\section{$3 \cdot 1$ 実験対象とした浮選回路}

対象回路として望ましい条件は，a）フィード流量が測 定可能であること，b）セル有効容積が測定できること，

c) フロスの系内繰返しがないことなどである。また厳密 にはフロス流量も無視できない。現場の浮選回路でこれら の条件を十分に満たすものは少ない。当工場においては次 の 4 回路を実験対象とした。

(1) バルク浮選第 2系列 1 次粗選回路 (B 2-1R)

この系統はワーマン\# 48 浮選機の6セル直列槽であり ( 以 下WN と略記 ), 元来フリーフロー方式であつたものを 一部改造して, 逆混合流を抑制している。 Fig. 2に示すよ うに, 浮選フィード流量は, 電磁流量計によりオンライン 測定され，その $1 / 3$ 量が第 2 系列にフィードされている。 また 2 次粗選回路 (2R)のフロスは $1 \mathrm{R}$ 第 2 セルに繰返 されている。当回路へのフィード流量を, ボールミルへの 鉱石フィード量と水量を変えることにより2段階に変更し て，それぞれの定常状態におけるパルプの滞留時間分布を

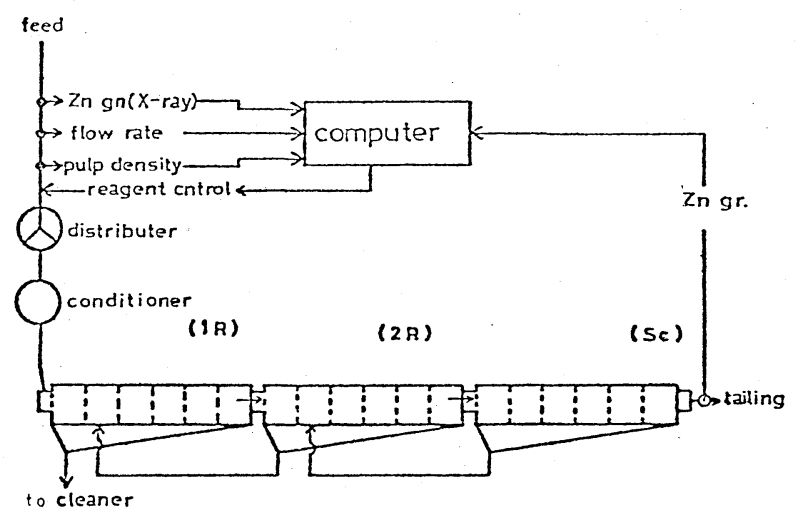

Fig. 2 Bulk flotation circuit-No.2 (B2) 
測定した。

（2）バルク浮選 2次清掃回路 この系統はVフロー\# 80 浮選機の 2 セル直列槽であり ( 以下 VF と略記 ), バ ルク浮選 1 次清掃テーリングの 2/3 量 ( B2-Sc,B3-Sc のテーリング ) がフィードされている。

(3) 分離浮選清掃回路 ( D-Sc) この系統はフリー フロー方式のアジテア＃60 浮選機の 4 セル直列槽である (以下AG と略記 )。実験は分離浮選 2 次粗選回路 ( D $2 \mathrm{R}$ ）に繰返されているフロスを，暫時停止することによ り，清掃回路へのフィード流量を 2 段階に変えて行なつた。 しかし，フィード流量の測定は困難であつたため，テーリ ング流量のみを四角せき水頭より測定した。セル間隔壁の 空の大きさは, 流れ方向に直角のセル断面に対して約 30 \%であつた。

（4） I PU浮選粗選回路 この系統はナガーム浮選機 の 6 セル直列回路で (以下NA と略記 ), フィード流量の 測定は困難であつたため, 工場側のデータを利用した。

\section{$3 \cdot 2$ インパルス応答試験の方法}

$10 l$ の水に $2 \sim 3 \mathrm{~kg}$ の食塩を溶解し，この液を各回路の フィードボックスに瞬間的に注入し，パルプレベル計を改 造した電極により, 排鉱ボックスにおける食塩濃度の経時 変化を電導度の変化として捉え, インパルス応答の検出を 行なつた。検量線はこの実験の範聿内でほぼ值線となつた。

\section{$3 \cdot 3$ インパルス応答試験の結果および考察}

（1）浮選セル有効容積および逆混合割合 $\alpha$ の決定 空 気混和時のパルプレベルから計算されるセル容積を見掛け 容積 $V_{p}$ とし,インパルス応答から次式により推定されるセ ル容積を $V_{E}$ とした。

$$
V_{E}=Q \cdot \theta_{E}=Q \cdot \int_{0}^{\infty} t \cdot g(t) d t
$$

ここで $\theta_{E}$ :インパルス応答より推定される 平均滞留時間

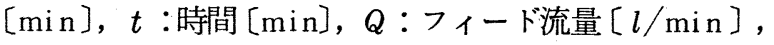
$g(t):$ イソパルス応答 $\left[\mathrm{min}^{-1}\right]$ である。

インパルス応答曲線のピークに対応する時間 $T_{p}$ を $\theta_{E}$ で 除して $\phi_{p}\left(=T_{p} / \theta_{E}\right)$ を求め, 逆混合モデルのパラメータ $\alpha$ と $\phi_{p}$ の関係を示す Fig. 3 より, 一次近似として各 $\phi_{p}$ に対応する $\alpha_{p}$ を求めた。Table 1にこれらのデータを一 括して示す。WNについては, フロス繰返しのため $\theta_{E}$ が 過大となり，適当なデータが得られなかつた。

V FおよびN Aについては $\alpha_{p}$ がゼロとなつた。これは完 全混合槽直列モデルに対応することを意味する。そこでそ の性質を利用してセル容積の推定を試みた。

$$
\begin{aligned}
& g_{m}(t)=\left(\frac{Q}{V}\right)^{m} \frac{t^{m-1}}{(m-1) !} \exp \left(-\frac{V}{Q} t\right) \\
& \log \left\{g_{m}(t) / t^{m-1}\right\}=\log \left\{\left(\frac{Q}{V}\right)^{m} \frac{1}{(m-1) !}\right\} \\
& -\frac{Q}{V} t \cdot \log e
\end{aligned}
$$

ここでmはセル数，Vはセル有効容積を表わす。VF， $\mathrm{NA}$ およびWNについて $\log \left\{g_{m}(t) / t^{m-1}\right\}-t$ プロットか ら得られる直線の勾配 $r$ から, 平均滞留時間 $\theta_{r}$, およびセ ル容積 $V_{r}$ を推定した。AGについては直線近似が困難であ
つたため, 推定値は得られなかつた。

$$
\theta_{r}=Q / V_{r}=0.4343 / r
$$

これらの一次近似值を用いて, 逆混合モデルの計算機シ ミュレーションにより, 誤差の平方和を最小にするセル有 効容積, 逆混合割合および平均滞留時間の最適值を, それ ぞれ $V, \alpha, \theta_{T}$ として求めた。ただし，VFおよびNAに 関しては，ピストンフロー部分（その容積を $V_{L}$ とする）を 直列に付加した形式の逆混合モデルによつた。これらの值 も Table 1に示してある。なお添字 j はセル番号を表し $V_{j}=V / m$ である。Fig. 4 およびFig. 5 にインパルス応答 曲線を示す。図において○， $\triangle$ の点は実験値, 実線は計算 値を表わす。実験データと計算結果はいずれも良好な一致 を示している。この結果, 実操業浮選セルの流れ特性は, 基本的に逆混合モデルで記述し得ることが確認された。

（2）考察 フリーフロー方式のAGに関して, 実験室 試験結果からの類推により, 逆混合割合 $\alpha$ とィード流量 $Q$ の間に，

$$
\alpha=\alpha_{1}^{\prime} / Q ， \quad \alpha_{1}^{\prime}=900[\mathrm{l} / \mathrm{min}] .
$$

という実験式が得られた。

WNに関しては, 逆混合流抑制のための改造により，滞 留時間分布が改善されていることが確認された。）VFおよ びNAに関しては，七ル連絡用パイプなどにおける滞留時 間を表わすピストンフロー部分を付加することが必要であ つた。これらの関係を Fig. 6 に示す。

セル有効容積は設計上の幾何形状のみでなく, インペラ

\begin{tabular}{|c|c|c|c|c|c|c|c|}
\hline \multicolumn{2}{|c|}{ experiment } & WN 1 & WN 2 & $A G 1$. & AG 2 & VF & NA \\
\hline $\mathrm{m}$ & - & 6 & 6 & 4 & 4 & 2 & 6 \\
\hline$Q$ & $1 / \min$ & 1370 & 1167 & 963 & 696 & 2041 & 1500 \\
\hline$V_{j b}$ & 1 & 630 & 590 & 1550 & 1530 & 2800 & 2200 \\
\hline$\theta_{E}$ & $\min$ & 2.61 & 2.62 & 4.67 & 6.45 & 2.31 & 7.08 \\
\hline$v_{j E}$ & 1 & - & - & 1123 & 1122 & 2360 & 1770 \\
\hline$T p$ & $\min$ & 1.9 & 1.8 & 2.3 & 2.9 & 1.25 & 5.75 \\
\hline$\phi \mathrm{p}$ & - & - & - & 0.50 & 0.46 & 0.54 & 0.81 \\
\hline$\alpha p$ & - & - & - & 1.0 & 1.3 & 0 & 0 \\
\hline$\theta r$ & $\min$ & 2.00 & 2.10 & - & - & 2.15 & 6.85 \\
\hline$V_{j r}$ & 1 & 460 & 410 & - & - & 2200 & 1750 \\
\hline$V_{j}$ & 1 & 456 & 408 & 1100 & 1100 & 2192 & 1650 \\
\hline$v_{L}$ & 1 & 0 & 0 & 0 & 0 & 255 & 1400 \\
\hline$\theta_{\mathrm{T}}$ & $\min$ & 2.00 & 2.10 & 4.56 & 6.32 & 2.27 & 7.53 \\
\hline$\alpha$ & - & 0 & 0 & 0.94 & 1.29 & 0 & 0 \\
\hline$V_{j} / V_{j} b$ & - & 0.72 & 0.69 & 0.71 & 0.72 & 0.78 & 0.75 \\
\hline
\end{tabular}
部分, フロスオーバフローリップの高さ，パルプレベルお よび空気混合量に依存すると考えられる。本実験において 採用した, インパルス応答 $g(t)$ からセル容積 $V_{E}$ 年推定

Table 1 Estimation of effective volume of cells and back-flow ratio

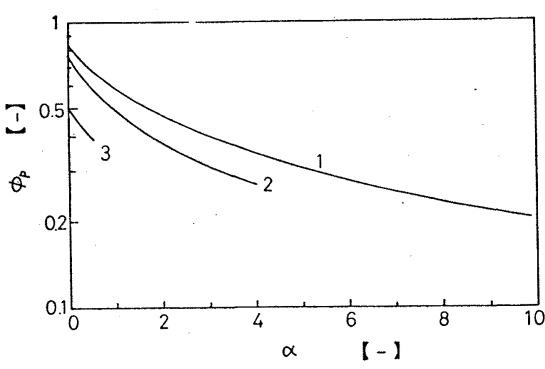

1: 6 cells, 2: 4 cells, 3: 2 cells.

Fig. 3

Relationship between $\phi p$ and $\alpha$ of back-flow model 

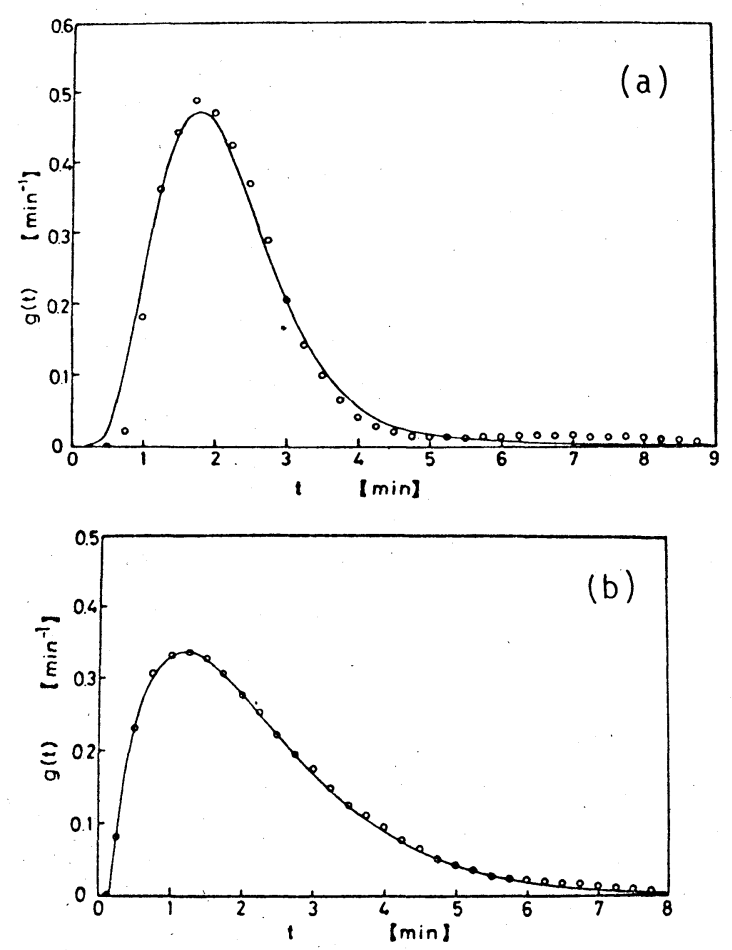

(a):WN2, (b):VF

Fig. 4 Impulse response curves

する方法は, 浮選結果に与える影響が少なく，実用性の高 いものであろう。浮選系設計の際あるいはシミュレーショ ンにおいては, 見掛け容積に対する有効容積の比 $\left(V / V_{b}\right)$ に関するデータを蓄積して，セル有効容積が決定されるべ きである。逆混合割合 $\alpha$ につても，セル間の空の大きさ インペラ回転速度, フィード流量などに関するデータを蓄 積することにより，予測が可能となるものと考えられる。

\section{4. 半回分式浮選試験}

\section{$4 \cdot 1$ 実験装置および方法}

鹿間選鉱工場で処理している鉛・亜鉛鉱石サンプルにつ いて，第 2 報に記述した実験装置および方法により ${ }^{3)}$ ，゙ル ク浮選第 1 粗選に対応する半回分式浮選試験を実施し，鉱 物および水の浮選速度を推定した。実験のパラメータとし て空気導入量，パルプレベルおよびフィード覀鉛品位を採 用し，浮選条件は実操業と同一にすることを目指した。た だし，実操業ではワーマソ\# 48 浮選機を使用していたが， 実験室では小型のアジテア式浮選試験機を使用した。また 粗粒沈積を防ぐため, フィード粉研粒度はー74 4 66.1\% (実操業では $56.4 \%$ ) とした。浮選試薬添加量は, 当該工 場で実施されている方法に従つて次のように決定した。
捕收剂 $\mathrm{NaEX}$
$:\left(z_{n f}-1.01\right) \times 1.73+8[\mathrm{~g} / \mathrm{t}]$

活性剤 $\mathrm{CuSO}_{4} \cdot 5 \mathrm{H}_{2} \mathrm{O}:\left(z_{n f}-0.54\right) \times 11.7+40[\mathrm{~g} / \mathrm{t}]$

さらに起泡剂としてタカサ KEを $28 \mathrm{mg} / l$, 青化ソーダ $(\mathrm{NaCiN})$ を $10 \mathrm{~g} / \mathrm{t}$ 添加し ${ }^{6)} \mathrm{pH}$ は炭酸ナトリウム $\left(\mathrm{Na}_{2} \mathrm{OO}_{3}\right)$ により 10.0 に調整した。

\section{$4 \cdot 2$ 半回分式浮選結果および考察}

フロスサンプルの亜鉛品位抢よび鉛品位から，閃亜鉛鉱 $(\mathrm{ZnS})$ 拉よび方鉛鉱 $(\mathrm{PbS})$ の重量をそれぞれ求め, 残り
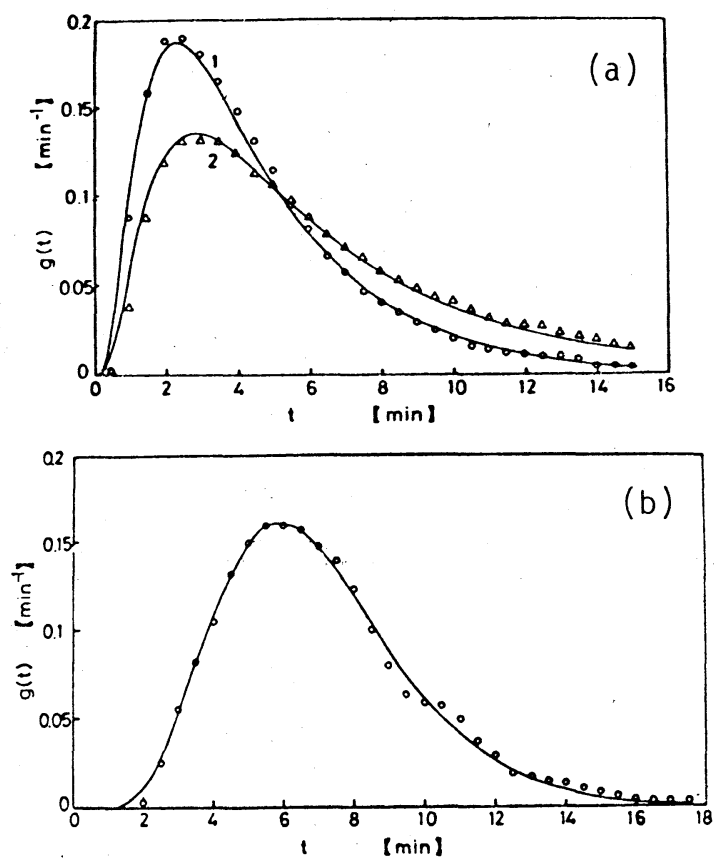

(a) 1:AG1, 2:AG2

(b) :NA

Fig. 5 Impulse response curves

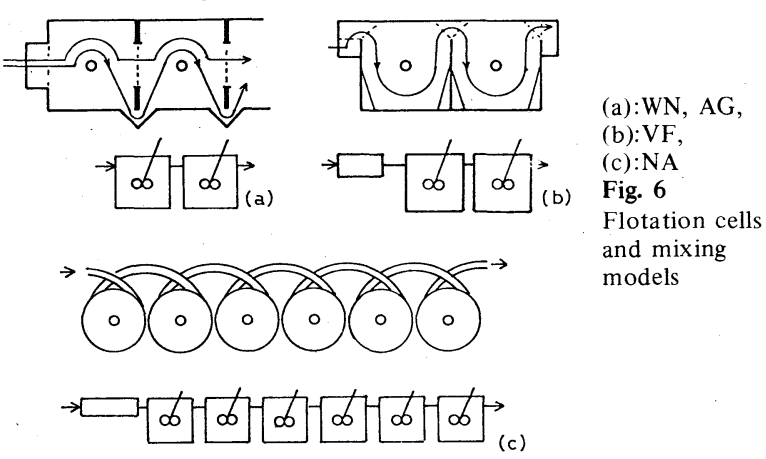

の固体はすへて脈石として解析し，それぞれの浮選速度曲線 を得た。その一部をFig.7 に例示する。な打水の浮選速度 曲線に関しては, 補給水の量を無視した。実験条件および $10 \mathrm{~min}$ 後の浮選結果 (Table 2) より, 各実験パラメータ の影響を明らかにすることを試みた。

（1）水の浮選挙動 水のフロスへの回収率は浮選初期 に著しく，以後急激に減少する傾向が認められた。フロス 層が厚く形成されている浮選初期には，鉱物および水は多 量に回収されるが，その後浮遊すべき鉱物量が減少するた め, フロス層厚は減少し, 水の回収率が急激に低下寸るも のと考えられる。水を浮選フィードパルプの1成分と見な し，またフロス相モデルを含まない当該プロセスモデルに より,この現象を記述するため, 水の浮選速度定数が見掛 け上分布するものとした。この点，前報に記載した銅鉱石 の場合は，水のフロスへの回収率が時間的にほぼ一定であ り，1つの速度定数を対応させることができた。

(2) 空気導入量およびパルプレベルの影響 空気導入 量が水㧍よび脈石実収率に与える影響は，各パルプレベル， ファード吿鉛品位 $\left(z_{n f}\right)$ に対して, ほぼ一定の正の傾きを 持つた直線で表わされる。パルプレベルの影響は， $z_{n f}$ が 高い場合 $\left(z_{n f} \geqq 4\right)$ 一定の正の傾きを持つた直線で近似で 
きる。水の実収率を一定とした場合，脈石実収率は空気導 入量よりもパルプレベルによつて大きく影響されることが 認められた。

（3）水および脈石の実收率の関係＼cjkstart水㧍よび脈石の実 収率については, Fig.8に示されるように，帯状の領域で 示される正の相関関係が得られた。

実線はパルプレベル，破線は空気導入量の影響をそれぞ れ示している。図において○に付した数字はTable 2 の実
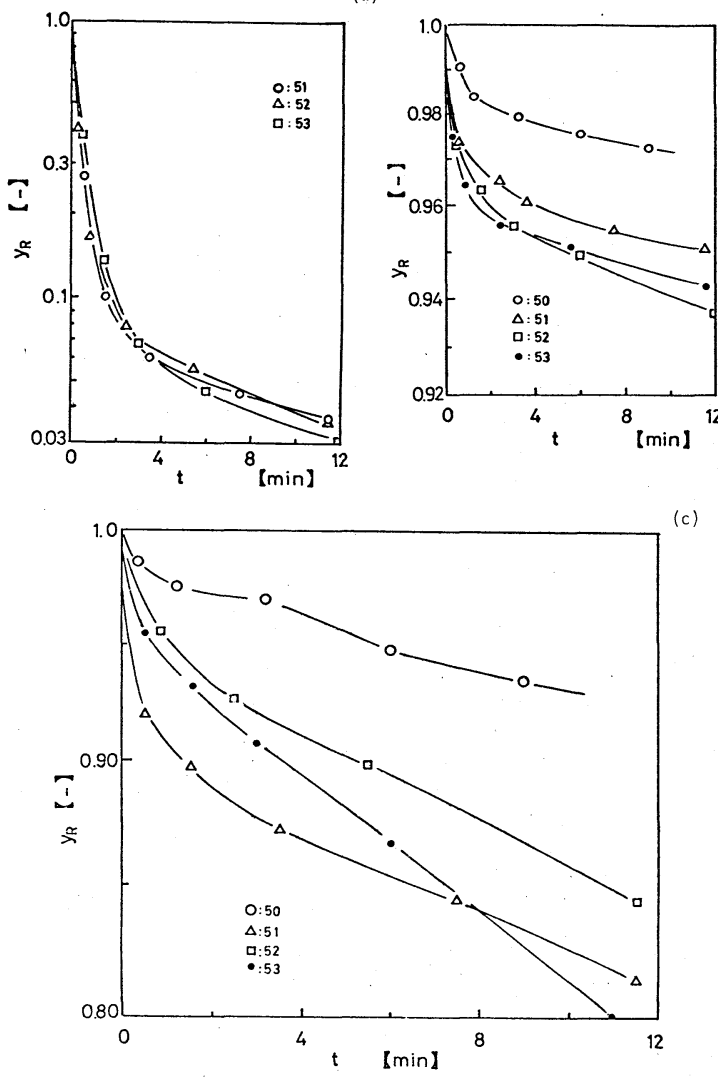

(a) : $\mathrm{Zn}$, (b) : Gangue, (c) : Water

Fig. 7 Flotation rate curves (semi-batch)

Table.2 Results of semi-batch flotation test after 10 minutes

\begin{tabular}{|c|c|c|c|c|c|c|c|}
\hline \multirow{3}{*}{$\begin{array}{l}\text { exper. } \\
\text { No. }\end{array}$} & \multirow{3}{*}{$\begin{array}{l}\text { pulp } \\
\text { level } \\
\text { mm }\end{array}$} & \multirow{3}{*}{$\begin{array}{l}\text { aera- } \\
\text { tion } \\
1 / \mathrm{min}\end{array}$} & \multirow{3}{*}{$\begin{array}{c}\text { Zn gr. } \\
\text { of feed } \\
\%\end{array}$} & \multirow{3}{*}{$\begin{array}{l}\text { pulp } \\
\text { dens. } \\
\%\end{array}$} & \multicolumn{3}{|c|}{ RECOVERY } \\
\hline & & & & & & gangue & water \\
\hline & & & & & $\%$ & $\%$ & $\%$ \\
\hline 40 & 77.5 & 2.0 & 2.78 & 38 & 93.1 & 1.70 & 6.00 \\
\hline 41 & 77 & 1.9 & 2.71 & 22 & 92.2 & 1.37 & 4.75 \\
\hline 42 & 77 & 1.9 & 2.66 & 22 & 93.1 & 1.25 & 3.75 \\
\hline 43 & 76.5 & 1.9 & 2.75 & 31 & 93.2 & 1.21 & 3.70 \\
\hline 44 & 76.5 & 2.0 & 2.76 & 38 & 93.5 & 1.30 & 5.15 \\
\hline 45 & 77 & 2.2 & 2.75 & 38 & 93.8 & 1.65 & 6.96 \\
\hline 46 & 76.5 & 2.0 & 2.69 & 22 & 92.6 & 1.31 & 5.00 \\
\hline 47 & 77 & 1.9 & 2.73 & 38 & 92.2 & 1.39 & 4.45 \\
\hline 48 & 76.5 & 1.7 & 6.88 & 38 & 93.6 & 2.55 & 3.45 \\
\hline 49 & 76.5 & 1.9 & 4.78 & 38 & 94.5 & 2.05 & 3.88 \\
\hline 50 & 77 & 2.0 & 5.84 & 38 & 95.9 & 2.81 & 7.00 \\
\hline 51 & 78 & 2.6 & 6.45 & 37 & 96.0 & 4.85 & 17.40 \\
\hline 52 & 78 & 2.0 & 7.20 & 30 & 96.1 & 5.51 & 14.20 \\
\hline 53 & 78 & 2.4 & 7.34 & 37 & 96.6 & 5.95 & 18.60 \\
\hline $54 *$ & 78 & 2.0 & 6.45 & 37 & 96.1 & 4.40 & 13.00 \\
\hline$\underline{55^{\star}}$ & 76.5 & 3.0 & 6.88 & 37 & 95.9 & 3.90 & 12.00 \\
\hline
\end{tabular}

* froth was taken as one sample through 10 minutes.
験番号を表わしている。はは内挿あるいは外插により求め た点である。

\section{5. 実操業浮選結果とそのシミュレーション}

\section{$5 \cdot 1$ 実操業浮選結果}

B 2-1R 系統において, 先に述べたインパルス応答試験 と同時期に，定常状態でのフィード，テーリングおよび各 セルからのフロスをサンプリングして，浮選結果を解析し た。その一部をTable 3に示す。第 1 セルにおけるフロス 流量が極めて大きく, 全フロス量の約 $50 \%$ が回収されて いることは, 実験室半回分式浮選の傾向に対応している。 また，一方，フロス層およびパルプ層高さ方向のサンプリ ングを実施した結果, パルプ層内における各成分の分布が, 高さ方向にほぼ均一であること，およびフロス層内におい て濃縮と選別が行なわれていることが認められた。

\section{$5 \cdot 2$ シミュレーション}

（1）シミュレーションモデル Fig. 2 に示す浮選回路 について，2章に述べたように微分方程式で記述された数 学モデルを作成し, 計算機シミュレーションを行なつた。

（2）比較の規準 実験室用小型浮選機による半回分式 浮選と, 実操業の大型浮選機による連続式浮選の結果を対 比する際に, 試薬添加量などの浮選条件は可能な限り同一 とした。浮選機サイズの相違を補正するため, スケールア ップの規準として, Arbiter $\check{~}^{8)}$ により, 次式で表わされ る air flow number $N_{Q}$ が提案されている。

$$
N_{Q}=Q_{a} / I \cdot D_{I}^{3}
$$

ここで $Q_{a}$ : 空気導入量, $I$ : インペラ回転速度, $D_{I}$ : イ ソペラ直径である。 $N_{Q}$ は単位面積当たりの空気導入量に対 応する $\left(Q_{a} / D_{I}^{2}\right)$ とインペラ周速 $\left(I \cdot D_{I}\right)$ の比を表わす。 本実験において $N_{Q}$ を比較すると，

\begin{tabular}{l|r|r|c|c}
\hline & $I[\mathrm{rpm}]$ & $D_{I}[\mathrm{~cm}]$ & $Q_{a}[l / \mathrm{min}]$ & $N_{Q}[-]$ \\
\hline 実験室 & 1140 & 5 & $1.7 \sim 3.0$ & $1.2 \sim 2.1 \times 10^{-2}$ \\
実操業 & 400 & 43 & $1,300 \sim 1,700$ & $4.1 \sim 5.3 \times 10^{-2}$ \\
\hline
\end{tabular}

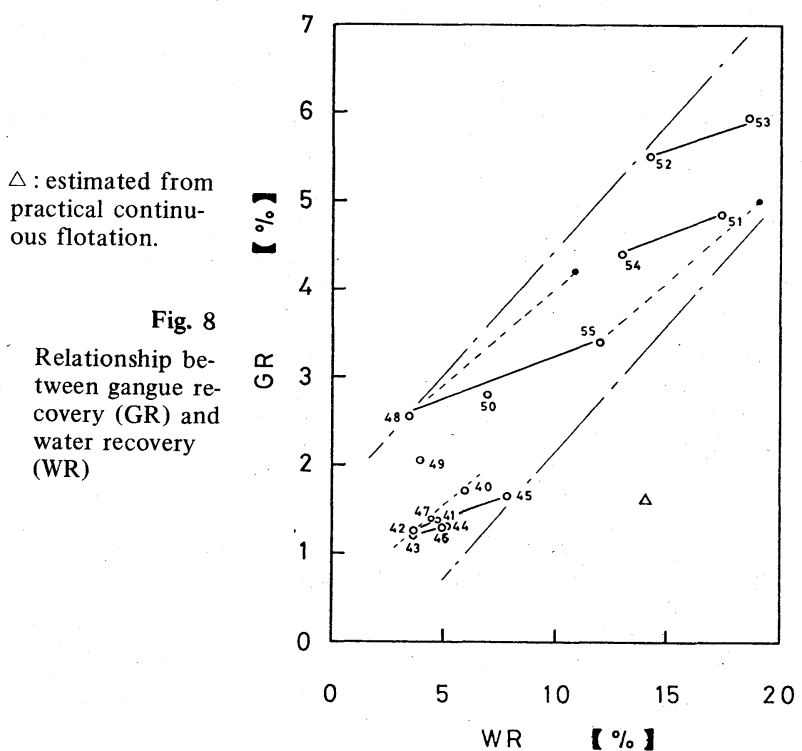


実操業浮選プロセスの速度論的解析 $\square$

Table 3

Results of B2-1R flotation in steady state

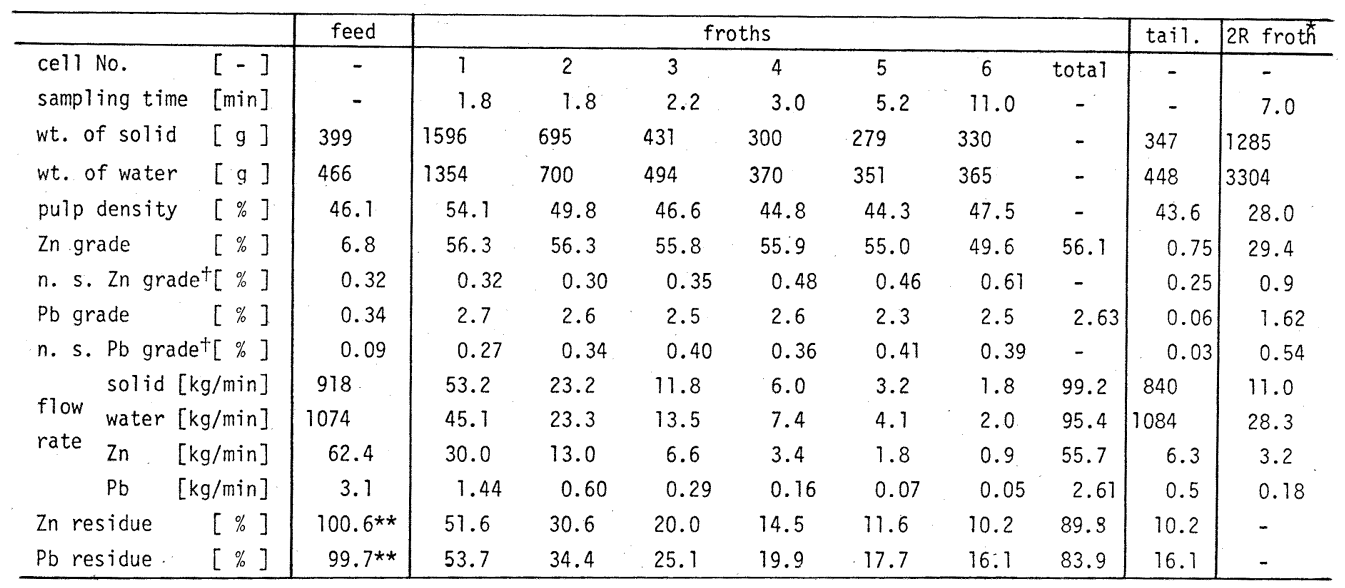

* flow rate of water fed to froth launder of $2 \mathrm{R}$ bank $=1.227 \mathrm{l} / \mathrm{sec}=73.6 \mathrm{l} / \mathrm{min}$,

** froths plus tail. $=100[\%]$,

+ "n.s." refers to non-sulphide

1976/09/03 9:45-10:15

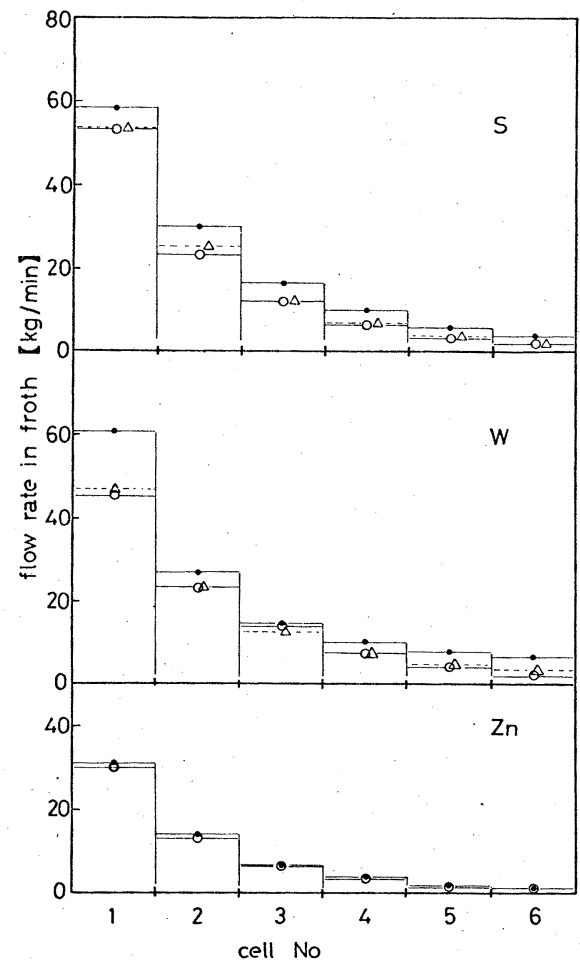

$O$ : measured,

- simulated with ssemi-batch data (No. 51)

$\triangle$ : simulated with practical continuous data.

Fig. 9

Flow rate in froth of solid(S), water(W) and $\mathrm{Zn}$.
Table 4 Input data of simulation

\begin{tabular}{|c|c|c|c|c|c|}
\hline \multicolumn{6}{|c|}{$\begin{array}{l}\text { Simulation of B2-1R flotation in steady state ( I } \\
\text { No. of semi-batch flotation test }\end{array}$} \\
\hline \multicolumn{3}{|c|}{ feed rate of pulp $Q$. } & \multicolumn{3}{|c|}{$1371[\mathrm{l} / \mathrm{min}]$ (solid $918[\mathrm{~kg} / \mathrm{min}])$} \\
\hline \multirow{2}{*}{\multicolumn{3}{|c|}{$\begin{array}{ll}\text { volume of cells } & V \\
\text { back-flow ratio } & \alpha \\
\end{array}$}} & \multirow{2}{*}{\multicolumn{3}{|c|}{$\begin{array}{r}2736[\ell] \quad(456 \times 6) \\
0[-]\end{array}$}} \\
\hline & & & & & \\
\hline \multirow{3}{*}{$\begin{array}{c}\text { comp. } \\
\text { No. } \\
i\end{array}$} & \multirow{3}{*}{$\begin{array}{c}\text { mineral } \\
\text { species } \\
-\end{array}$} & \multirow{3}{*}{$\begin{array}{c}\text { spec. } \\
\text { grav. } \\
-\end{array}$} & \multirow{2}{*}{ ki } & \multicolumn{2}{|l|}{ feed } \\
\hline & & & & & \\
\hline & & & $\min ^{-1}$ & \multicolumn{2}{|l|}{$\mathrm{kg} / \mathrm{min}$} \\
\hline 1 & water & 1.0 & 0.0086 & 964.5 & \\
\hline 2 & water & 1.0 & 0.7328 & 35.58 & \\
\hline 3 & water & 1.0 & 6.05 & 74.02 & \\
\hline 4 & sphale. & 4.1 & 0.0491 & 6.116 & \\
\hline 5 & sphale. & 4.1 & 0.9263 & 12.7 & \\
\hline 6 & sphale. & 4.1 & 2.554 & 17.4 & \\
\hline 7 & sphale. & 4.1 & 4.265 & 56.78 & \\
\hline 8 & galena & 7.58 & 0.0333 & 0.5044 & \\
\hline 9 & galena & 7.58 & 0.7631 & 0.4779 & \\
\hline 10 & galena & 7.58 & 3.598 & 2.597 & \\
\hline 11 & gangue & 2.98 & 0.0011 & 790.8 & \\
\hline 12 & gangue & 2.98 & 1.584 & 30.67 & \\
\hline \multicolumn{2}{|c|}{ Zn grade } & 6.8 & $\%]$ & (sphalerite & $10.1[\%])$ \\
\hline \multirow{2}{*}{\multicolumn{4}{|c|}{$\begin{array}{l}\text { water fed to } 2 \mathrm{R} \text {-froth launder } \\
\text { water fed to } \mathrm{SC} \text {-froth launder }\end{array}$}} & $73.6[\mathrm{l} / \mathrm{min}]$ & \\
\hline & & \multicolumn{2}{|c|}{ water fed to Sc-froth launder } & $73.6[\mathrm{l} / \mathrm{min}]$ & \\
\hline
\end{tabular}

番号 51 を選んだ。（ただし， $z_{n f}$ は実操業 $6.8 \%$ に対し て $6.45 \%$ とやや低く，水の実収率は $8.88 \%$ に対して 11.0 \%と多少高い。)

（3）浮選速度定数とその分布 ます閃覀鉛鉱 4 , 方鉛 鉱 3 , 脈石 2 および水 3 個の浮選速度定数区分とその分布 率をそれぞれ求め(成分数は合計 12 個となる), 次いで実 操業浮選のフィード亜鉛品位, パルプ濃度およびパルプフ ィード流量を基に，各成分の分布率に従い，それぞれのフ ィード量を決定し, シミュレーションの入力データとした (Table 4 )。

（4）シミュレーションの結果シミュレーションの結 果はFig.9にみられるように, 亜鉛の浮選挙動に関しては 良好な一致を示している。また鉛に関しても同様に良好な 一致が得られた。しかしフロスーの固体流量および水流量 に関して, シミュレーションによる計算值か実操業結果を 多少上回つている。これは部分的には, 実験番号 51 の水 
の実収率がやや大きめな值であつたことによる。しかし， 水の実収率の等しいデータを使用した場合，水に関しては 良い一致を示すことが予期されるが，Fig. 8における帯状 の相関関係から，脈石に関しては期待できず，したがつて フロスへの固体流量に関しても良好な一致は予期できない。

\section{$5 \cdot 3$ 実操業浮選における水および脈石実收率の関係}

B 2-1R系統において, 各セルからのフロス流量および 2 Rからの循環フロス流量と射水量を無視して, 各セルか らの水および脈石の回収率に基づき, 連続式浮選速度曲線 を描き，またセルの流れ特性が逆混合モデルで $\alpha=0$ ，す なわち完全混合槽直列モデルで記述されることを考慮して, 浮選速度定数とその分布率を求めた。 回分式浮選の $10 \mathrm{~min}$ 後の実収率にそれぞれ換算したとこ ろ, Fig. 8 に合せて $\triangle て ゙$ 示すように, 正相関を示す帯状の 領域から大きく右下に偏倚した。またこれらの速度定数と その分布率に基づいた連続式浮選のシミュレーション結果 は, 実操業浮選結果と良く一致している (Fig.9)。実験室 において，このような結果を示す半回分式浮選を実現する ためには，Fig. 8より推論して，パルプレベルを下げるか， 空気導入量を多くする必要があると考えられるが，そのよ うな条件では，正常な浮選は困難であつた。

\section{$5 \cdot 4$ 考察}

水および脈石の実収率の関係が，実操業と実験室とで相 違したことに関して種々の原因が考えられるが，フロス層 内における濃縮・選別効果を考慮すると, とくに浮選機サ イズの差によるフロス層厚の相違が大きな要因であると推 論できる。この定量的な解明は今後の課題であろう。例え ば，実験室において深い浮選七ルを使用することにより， フロス層厚に関しても, 実操業の浮選に対応する相似性の 高い半回分式試験が実施しうるものと考えられる。

\section{6. 結論}

三井金属鉱業 (株) 神岡鹿間選鉱工場における実操業浮選 プロセスについて，パルプの滞留時間分布を測定した結果， 実操業浮選セルの流れ特性は基本的に逆混合モデルで記述 しうることが認められた。とくにフリーフロー方式のアジ
テア浮選機に関しては, 逆混合割合 $\alpha$ がフィード流量に逆 比例すること，ワーマン浮選機に関しては，逆流抑制のた めの改造が滞留時間分布を改善することなどが認められた。

浮選過程が一次反応速度式に従い, その速度定数は離散 的に分布するものと想定し, また浮選七儿流れ特性を逆混 合モデルで記述して, 浮選プロセスの数学モデルを作成し た。実験室用小型浮選機における半回分式浮選の結果に基 づき，当該モデルによるシミュレーションを実行し，鉛・ 覀鉛鉱石の実操業バルク浮選結果と比較したところ, 鉛お よび亜鉛の浮選挙動に関して良好な一致が得られた。脈石 に関しては良い一致は得られなかつたが，水および脈石の 実収率とフロス層厚の関係について考察した結果, 浮選機 サイズの差によるフロス層厚の相違が，その大きな要因で あると推論された。これらの結果から, 鉛および亜鉛の浮 選挙動に関して当該プロセスモデルの妥当性が検証された。

なおシミュレーション計算には東京大学大型計算機セン ターHITAC 8800/8700 を利用した。また本研究は文 部省科学研究費補助金 (一般B ) 946036号, 並びに 146126 号によつたことを付記する。

終りに, 本研究を進めるに当たり, 実験の便宜を与えて頂 いた三井金属鉱業株式会社, 終始ご協力を頂いた同社鉱山 部 長浜達也氏, 同社神岡鉱業所 松井暢夫選鉱課長はじ め選鉱課諸氏に謝意を表する次第である。

\section{参考文献}

1) Dorenfeld, A. C. : Froth Flotation, Chap. 8, 50th Anniversary Vol., New York, AIME, 365 381, (1962)

2）柳沢·井上·今泉：日本鉱業会誌 93〔1077〕，879～884, (1977)

3）柳沢·井上·今泉：日本鉱業会誌 $94[1080], 91 \sim 96,(1978)$

4）日本鉱業会選鉱專門委員会：日本釷業会誌 $73[827] ， 307 \sim 323$, (1957)

5）松井 - 山崎 - 細岡 - 広川：日本鉱業会誌 91[1046]，273～277, (1975)

6）長浜：日本鉱業会誌 88 [1013]，401 408，(1972）

7) 石須: 日本鉱業会誌 86 [988], 465 470, (1970)

8) Arbiter, N., Harris, C. C. \& Yap, R. F. : Paper D-19, 8 th IMPC (1968), Leningrad

9）今泉·井上：日本鉱業会誌 $82[933] ， 17 \sim 24,(1966$ )

\section{Kinetic Analysis of a Practical Flotation Process}

\section{- Simulation of continuous flotation process (3rd Report) -}

by Yukihiko YANAGISAWA ${ }^{1}$, Toshio INOUE $^{2}$ and Tsunemasa IMAIZUMI ${ }^{3}$

In the former two reports the authors have developed a mathematical model of continuous flotation process with back-flow model describing the flow characteristics of flotation cells and with the first-order flotation reaction equation involving the discrete distribution of the rate constants.

In the present report the residence time distribution of the pulp was determined in different types of flotation cells in Shikama Concentrator in Kamioka, Mitsui Mining and Smelting Co. Ltd., to find out that the back-flow model could describe their flow characteristics adequately. The bulk flotation circuit of lead and zinc minerals in the plant was investigated under steady state conditions by the simulation model using the data of semi-batch flotation tests in the laboratory. The flotation behavior of the minerals could be approximated by this simulation fairly well. Thus the process model was proved to be valid for the simulation of a full-scale continuous flotation process of lead and zinc minerals.

(1. Dr., National Research Institute for Pollution and Resources, MITI $\quad$ 2. Assoc. Prof., Dr., Faculty of Engineering, $\begin{array}{ll}\text { The University of Tokyo } & \text { 3. Prof., Dr., Faculty of Engineering, The University of Tokyo }\end{array}$ 